One of the articles in this special issue discusses Chinese-African agricultural co-operation. The people presently engaged in the Chinese Agricultural Technology Demonstration Centers probably do not think about it, but proso millet travelled. It was first domesticated in Northern China (some even say ro,ooo years ago), and then it started spreading: to Afghanistan, to the Indus region, then on to Iran, Yemen, to reach Nubia some 2,000 years ago.

The story continued: during the seventh and eighth century, ivory from Southern Africa, for example, was used in Chinese luxury palanquins. Chinese glass beads, copper coins, and green-glazed stoneware: archaeological finds on the East and South coast of Africa testify to the longstanding connections over the Indian Ocean. The trading network not only connected China and the African coast, but also reached further inland. After all, Chinese blue on white porcelain was found at the Great Zimbabwe, dating from some time during the fourteenth and fifteenth century.

And of course, the famous giraffes. In the early 1400 s, several giraffes found themselves at the imperial court through the efforts of Chinese explorer Zheng He who visited Somalia and the Swahili Coast during his maritime voyages. Zheng He's story inspired the novel The Dragonfly Sea by Kenyan writer Yvonne Adhiambo Owuor, that - as is shown by Mingqing Yuan in this journal - offers a nuanced, personal story of hope that challenges the dominant representation of the relations between China and Africa.

Lieve Joris does the same: instead of the often-heard generalised narrative of the superpower intent on recolonising Africa, she offers the stories of resilient, creative individuals between China and Africa - 'a delicate tissue being woven'.

The history of the Cold War has probably informed much of the current politics of representation. The TAZARA Railway, built by some 30,000 Chinese railway technicians and a $\$ 400$ million loan from China to Tanzania and Zambia in the early 1970s, was at the time derisively labelled the 'Bamboo railway' by critics who regarded the aid as Chinese strategic interference in Africa. Similar assessments can be heard now - fifty years later as China finances road construction in DR-Congo. Has the interaction between China and Africa changed? What role does China play in peace-building and security in world politics at large, and in Africa in particular? How has media representation of China-inAfrica and Africa-in-China changed over the years? This latter question includes African media representation, as is discussed in this special issue for the case of Malawi.

The long history of China-Africa interaction has involved a diversity of items, from millet to porcelain and giraffes, or put otherwise, agriculture, trade and diplomacy. Similarly, 
in this special issue, the articles relate to many fields of inquiry: agriculture, transport, security, literature, media, political relations and finance. Together the articles show the breadth and dynamics of the manifold relations between Africa and China. The articles for the special issue are complemented by two additional articles, a research report and a review that cover HIV risk reduction, anti-grazing laws, milk systems, and racial relations: a plurality of interests that realises the multidisciplinary mission of Afrika Focus. These are times of change for the journal. From its inception nearly 35 years ago, Patrick Van Damme has been engaged in Afrika Focus as author and editor-in-chief. Here, in my first editorial, I want to thank him for this massive contribution and express my hopes that the changes may do justice to the long history of the journal. This issue is the last one to be published by the Africa Platform of Ghent University Association. As of 202I, Afrika Focus shifts to Brill that has over the years built up an excellent tradition of publishing on African Studies. Furthermore, Afrika Focus will become a joint undertaking of Ghent University's Africa Platform and the Centre for Humanities Research of the University of Western Cape, a co-operation we are looking forward to immensely. In all its decisionmaking, the board will stick to the main call of the journal: focus on/from Africa.

\section{Inge Brinkman}

Editor-in-Chief

\section{References}

Church, S.K. (2004). The Giraffe of Bengal: A medieval encounter in Ming China. The Medieval History Journal, 7(I), I-37.

Fuller, D.Q. \& Boivin, N. (2009). Crops, cattle and commensals across the Indian Ocean: current and potential archaeobiological evidence. Etudes Océan Indien, 42-43, 13-46.

Monson, J. (2004). Freedom Railway: the unexpected successes of a Cold War development project. Boson Review, December.

Wood, M. (2015). Divergent patterns in Indian Ocean trade to East Africa and southern Africa between the $7^{\text {th }}$ and $17^{\text {th }}$ centuries CE: The glass bead evidence. Afriques: Débats, méthodes et terrains d'histoire, 6.

Zhao, B. (2015). Chinese-style ceramics in East Africa from the 9th to I6th century: A case of changing value and symbols in the multi-partner global trade. Afriques: Débats, méthodes et terrains d'histoire, 6 . 